\title{
Review
}

\section{Are we HER-ting for innovation in neoadjuvant breast cancer trial design?}

\author{
Natasa Snoj ${ }^{1}$, Philippe L Bedard ${ }^{2}$, Evandro de Azambuja ${ }^{3}$, Fatima Cardoso ${ }^{1,2}$ \\ and Martine Piccart ${ }^{1,2}$
}

\author{
${ }^{1}$ Department of Medical Oncology, Institut Jules Bordet, Brussels, Belgium, Universite Libre de Bruxelles, 121 Blvd de Waterloo, 1000, Brussels, \\ Belgium \\ 2Department of Medical Oncology, Institut Jules Bordet, Brussels, Belgium, Breast International Group, 121 Blvd de Waterloo, 1000, Brussels, \\ Belgium \\ ${ }^{3}$ Breast Data Centre, Institut Jules Bordet, Brussels, Belgium, Universite Libre de Bruxelles, 121 Blvd de Waterloo, 1000, Brussels, Belgium
}

Corresponding author: Martine Piccart, martine.piccart@bordet.be

Published: 16 January 2009

This article is online at http://breast-cancer-research.com/content/11/1/201

(c) 2009 BioMed Central Ltd
Breast Cancer Research 2009, 11:201 (doi:10.1186/bcr2209)

surgery allows for the identification of two distinct prognostic groups: patients able to attain a pathologic complete response (pCR) with a favourable long-term outcome and those with residual disease at surgery who are at a high risk of relapse [6]. Unfortunately, there is no additional therapy that has been shown to improve survival for patients failing to achieve a pCR to an anthracycline-taxane regimen [7] and this group of chemoresistant patients is desperately in need of novel therapeutic options.

There are many unresolved clinical questions regarding the use of neoadjuvant chemotherapy and additional locoregional treatment $[5,6]$. Well-designed neoadjuvant studies can quickly generate important preliminary data on the efficacy of novel therapies based on short-term endpoints such as pCR. They also offer an excellent opportunity to study the impact of systemic therapies on breast cancer biology, to explore surrogate markers of response (such as functional imaging), and to select promising biomarkers for future validation studies. The traditional model of conducting initial trials in metastatic breast cancer patients with refractory disease following standard therapy has been disappointing, as it demands a lot of effort and requires a long time before the drug reaches adjuvant registration. In addition, many new agents thought to be successful at controlling minimal residual disease have failed to demonstrate the efficacy for patients with advanced disease. As a result, a new pathway to accelerate the clinical development of emerging therapies is sorely needed.

ATAC $=$ Arimidex, Tamoxifen, Alone or in Combination; CTC $=$ circulating tumour cell; DFS $=$ disease-free survival; GEP $=$ gene expression profiling; HER2 = human epidermal growth factor receptor 2; HR = hormone receptor; IBC $=$ inflammatory breast cancer; neoALTTO = Neoadjuvant Lapatinib and/or Trastuzumab Treatment Optimisation; NOAH = NeOAdjuvant Herceptin; OS = overall survival; pCR = pathologic complete response. 
The identification of the central role of the human epidermal growth factor receptor 2 (HER2) protein in the pathogenesis of HER2-overexpressing breast cancer is one of the greatest successes of modern oncology. Over the last 10 years, trastuzumab, a monoclonal antibody against the HER2 protein, has been approved for the treatment of HER2 ${ }^{+}$ breast cancer, and a variety of exciting novel anti-HER2directed therapies that are entering clinical testing have been developed. As such, HER2+ breast cancer represents the ideal paradigm for a discussion of targeted neoadjuvant breast cancer therapy. The purpose of this article is to review ongoing neoadjuvant randomised clinical trials in HER2 ${ }^{+}$breast cancer evaluating novel HER2-directed agents, with an emphasis on recent innovations in trial design, platforms for the evaluation of surrogate endpoints and translational research, and the challenges in conducting neoadjuvant research.

\section{Search strategy}

Ongoing clinical trials were identified using the ClinicalTrials.gov database on 22 May 2008 [8]. With the search terms 'neoadjuvant breast cancer' and 'HER2 positive', 29 studies were recognised; with the terms 'preoperative' and 'HER2 positive', no additional studies were identified. The selection was limited to neoadjuvant randomised clinical trials that include HER2 ${ }^{+}$breast cancer. Trials investigating trastuzumab as the only HER2 agent were excluded from the review as we wished to focus on the neoadjuvant trials introducing novel therapies for early breast cancer. With this strategy, nine studies were identified and these are listed in Table 1 and Figure 1. Information regarding clinical trial design was largely collected from the ClinicalTrials.gov library; additional data (where available) were retrieved from the ClinicalTrials.gov $\left(\mathrm{PDQ}^{\circledR}\right)$ database of the National Cancer Institute (Bethesda, MD, USA) and through personal communication with the principal investigators of individual studies.

\section{Prior randomised neoadjuvant studies in HER2+ disease}

Even in the absence of targeted therapy against the HER2 signalling axis, HER2 ${ }^{+}$breast cancer demonstrates a higher rate of $\mathrm{pCR}$ to traditional neoadjuvant chemotherapy [9]. A retrospective single-series study suggests that patients with HER2 ${ }^{+}$disease who experience a $\mathrm{pCR}$ to neoadjuvant chemotherapy (without anti-HER2 therapies) may experience a better disease-free survival (DFS) with long-term follow-up [10]. Three randomised studies in the neoadjuvant setting have evaluated the additional of trastuzumab to standard therapy (Table 2). After 42 of a planned 165 patients had been accrued, the M. D. Anderson study was initially stopped because the $\mathrm{pCR}$ rate with trastuzumab added to paclitaxel followed by 5 -fluoruracil-epirubicin-cyclophosphamide $(\mathrm{P} \rightarrow \mathrm{FEC})$ chemotherapy was $65 \%$ versus $25 \%$ with chemotherapy alone $[11,12]$. The larger NeOAdjuvant Herceptin (NOAH) trial reported similar findings with trastuzumab added to doxorubicin-paclitaxel followed by paclitaxel followed by cyclophosphamide-methotrexate-5-fluoruracil ( $\mathrm{AP} \rightarrow \mathrm{P} \rightarrow \mathrm{CMF}$ ) chemotherapy [13]. Interestingly, both of these studies administered anthracycline chemotherapy concurrently with trastuzumab and did not report a high rate of observed cardiac toxicity. However, the $16 \%$ rate of clinical grade $3 / 4$ congestive heart failure observed in the pivotal first-line metastatic trial with concurrent trastuzumab and doxorubicincyclophosphamide (AC) would suggest that this approach should not be employed outside of a clinical trial setting [14]. More recently, the GeparQuattro study evaluating epirubicin, cyclophosphamide, and docetaxel with or without capecitabine and/or trastuzumab before surgery reported a similar doubling in the observed $\mathrm{pCR}$ rate with the addition of trastuzumab as seen in the NOAH study [15], using a more conventional schedule of initiating trastuzumab after the completion of anthracycline therapy.

\section{Designs of the ongoing randomised neoadjuvant studies in HER2+ disease}

The majority of ongoing HER2-targeted trials are investigating the efficacy of lapatinib in the neoadjuvant setting for HER2 ${ }^{+}$ breast cancer (Table 1) [16-24]. Most of these studies use $\mathrm{pCR}$ as a primary endpoint. $\mathrm{pCR}$ has been proven to correlate with survival endpoints (DFS and OS) in neoadjuvant chemotherapeutic trials $[25,26]$ but its precise definition is still debated. Whereas early trials regarded pCR as the absence of tumour on pathologic slides in breast and axillary lymph nodes, some of the later trials defined pCR as the absence of tumour in breast only without considering nodal evaluation in the operative specimen. In addition, definitions of $\mathrm{PCR}$ in neoadjuvant trials do not consistently account for the presence of minimal residual cellularity and residual in situ carcinoma. Recently, it was shown that the extent of residual breast cancer burden, calculated as a continuous index based on primary tumour measurements (size and cellularity) and lymph node metastases (number and size), correlates with survival outcomes [27]. Therefore, it is clear that a unified definition of pathologic response for neoadjuvant trials is required, much like the recent consensus statement regarding standard efficacy endpoints (STEEP) for adjuvant trials in early-stage disease [28]. Unfortunately, the definitions of response endpoints in the ongoing neoadjuvant trials with novel anti-HER2 agents are inconsistent (Table 1). It should be noted that there is even less evidence regarding the correlation between the extent of residual breast cancer burden following neoadjuvant targeted therapy (with or without chemotherapy) and survival [12,29].

At the present time, pCR is not robust enough to replace survival as an endpoint for the registration of novel therapies. Even though pCR appears to identify a subgroup with a favourable prognosis $[6,25,30]$, therapies that improve the rate of $\mathrm{pCR}$ do not necessarily translate into long-term differences in survival, as demonstrated by the addition of taxane therapy in the NSABP (National Surgical Adjuvant Breast and Bowel Project) B-27 trial [6]. However, the evaluation of $\mathrm{pCR}$ in neoadjuvant studies can provide a 


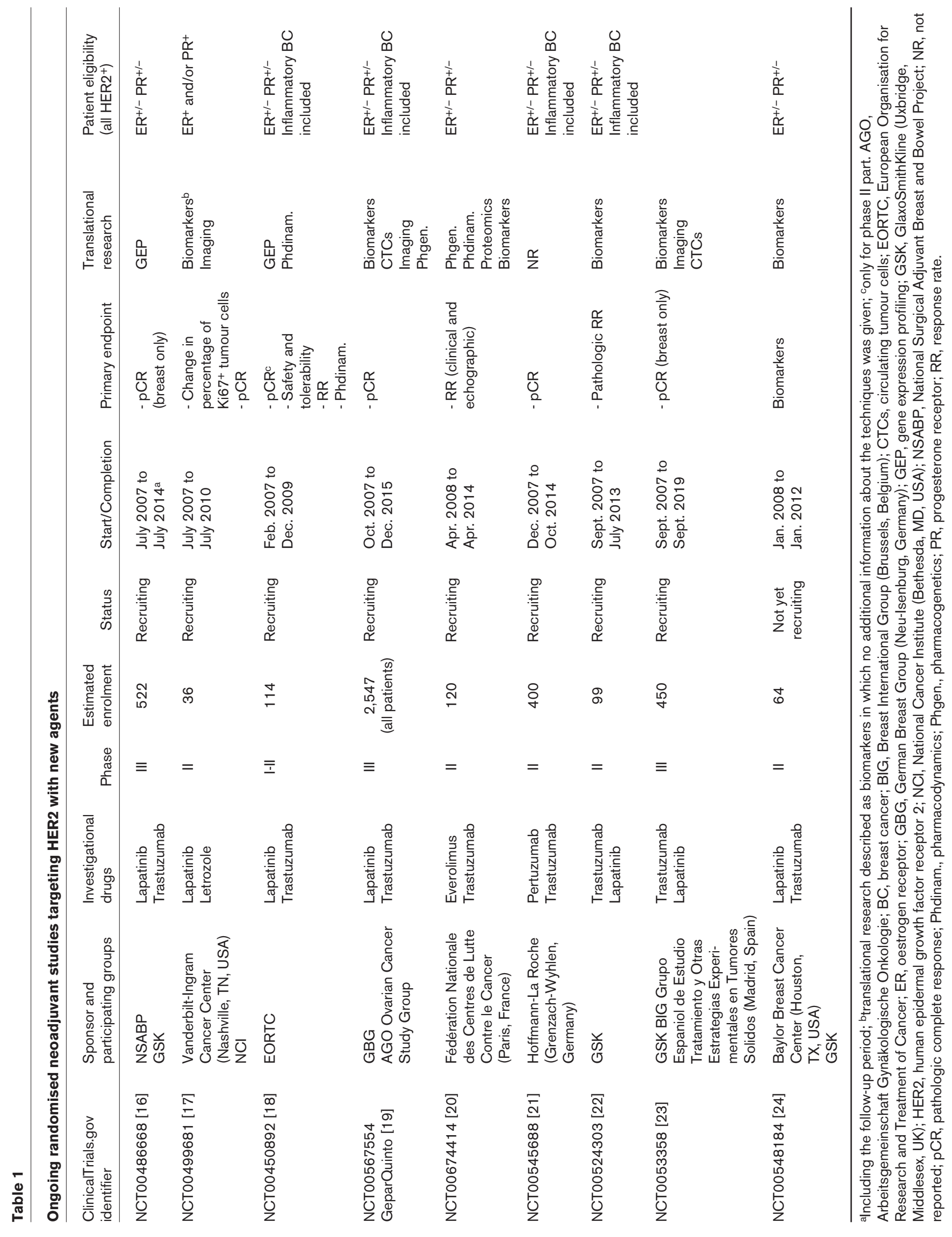


A study of $A C$ followed by a combination of paclitaxel plus trastuzumab or lapatinib or both given before surgery to patients with operable HER2-positive invasive breast cancer [16]

Letrozole and lapatinib in treating postmenopausal women with stage I, stage II, or stage III breast cancer that can be removed by surgery [17]

Docetaxel and lapatinib with or without combination chemotherapy or docetaxel and trastuzumab with combination chemotherapy in treating women with locally advanced, inflammatory, or resectable breast cancer [18]

A phase III trials program exploring the integration of bevacizumab, everolimus (RAD001), and lapatinib into current neoadjuvant chemotherapy regimens for primary breast cancer (GeparQuinto) [19]

Trastuzumab with or without everolimus in treating women with breast cancer that can be removed by surgery [20]

A study of pertuzumab in combination with herceptin in patients with HER2-positive breast cancer [21]

\section{breast cancer therapy [22]}

neoALTTO (Neoadjuvant Lapatinib and/or trastuzumab treatment optimization) study [23]

A phase II trial of lapatinib and trastuzumab with or without endocrine therapy in locally advanced HER2-overexpressing breast cancer patients [24]

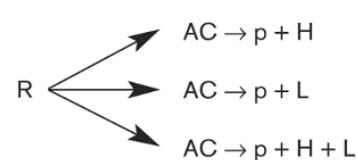

24 weeks

(12 weeks +12 weeks)

$[16]$

16 weeks

$\mathrm{R}$

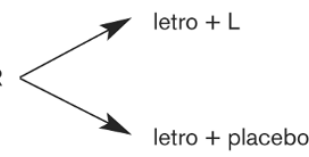

$\longrightarrow$ FEC $\rightarrow T+H$
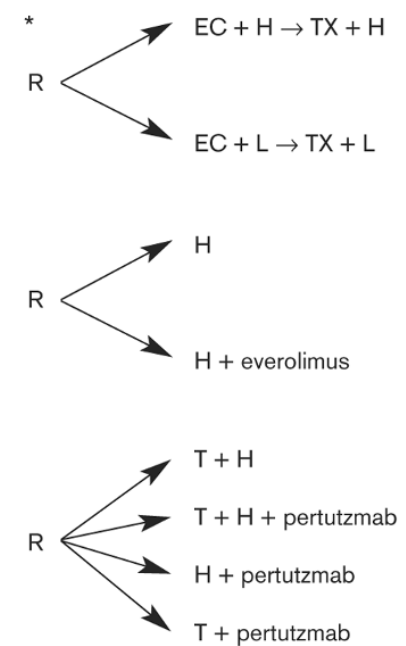

NR

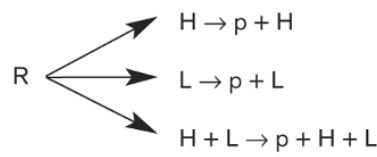

NR

NR
(9 weeks +9 weeks)

24 weeks

(12 weeks +12 weeks)
NR

6 weeks

NR

18 weeks

( 6 weeks +12 weeks)

Trial design of ongoing randomised neoadjuvant studies targeting HER2 with new agents. *Only the randomization for HER2 positive patients is presented. AC, doxorubicin-cyclophosphamide; EC, epirubicin-cyclophosphamide; FEC, 5-fluoruracil-epirubicin-cyclophosphamide;

$\mathrm{H}$, trastuzumab; HER2, human epidermal growth factor receptor 2; L, lapatinib; letro, letrozole; NR, not reported; $p$, paclitaxel; R, randomisation, $\mathrm{T}$, docetaxel; X, capecitabine.

critical early marker of efficacy, especially if a neoadjuvant study is coupled with a larger adjuvant registration trial using survival as its primary endpoint, such as in the case of the ongoing neoALTTO (Neoadjuvant Lapatinib and/or Trastuzu- mab Treatment Optimisation) and the ALTTO (Adjuvant Lapatinib and/or Trastuzumab Treatment Optimisation) trials. A similar model has been employed by the recently completed neo-tAnGo and tAnGo trials in nonselected 
Table 2

\begin{tabular}{|c|c|c|c|c|c|c|c|}
\hline \multirow[b]{2}{*}{ Reference } & \multirow{2}{*}{$\begin{array}{l}\text { Number } \\
\text { of } \\
\text { patients }\end{array}$} & \multirow{2}{*}{$\begin{array}{c}\text { Patient } \\
\text { population }\end{array}$} & \multirow[b]{2}{*}{ Design } & \multirow{2}{*}{$\begin{array}{c}\text { HER2 } \\
\text { assessment }\end{array}$} & \multicolumn{3}{|c|}{ pCR rate, percentage $(95 \% \mathrm{Cl})$} \\
\hline & & & & & $\mathrm{NoH}$ & With $\mathrm{H}$ & $P$ value \\
\hline $\begin{array}{l}\text { Buzdar et al., } \\
2005 \text { [11], } \\
2007 \text { [12] }\end{array}$ & 42 & $\begin{array}{l}65 \% \text { T2 } \\
40 \% \text { N0/ } \\
57 \% \text { N1 }\end{array}$ & $\begin{array}{c}\mathrm{P} \rightarrow \mathrm{FEC} \text { vs. } \\
\mathrm{P}+\mathrm{H} \rightarrow \mathrm{FEC}+\mathrm{H}\end{array}$ & $\begin{array}{l}\mathrm{IHC} 3+\text { or } \\
\mathrm{FISH}+\end{array}$ & $\begin{array}{c}26 \\
(9-51)\end{array}$ & $\begin{array}{c}65 \\
(43-84)\end{array}$ & NS \\
\hline $\begin{array}{l}\text { Gianni et al., } \\
2007 \text { [13] }\end{array}$ & 228 & $\begin{array}{l}60 \% \mathrm{~T} 4 \\
85 \% \mathrm{~N}+\end{array}$ & $\begin{array}{c}\mathrm{AP} \rightarrow \mathrm{P} \rightarrow \mathrm{CMF} \text { vs. } \\
\mathrm{AP}+\mathrm{H} \rightarrow \mathrm{P}+\mathrm{H} \rightarrow \\
\mathrm{CMF}+\mathrm{H}\end{array}$ & $\begin{array}{c}\mathrm{IHC} 3+\text { or } \\
\text { FISH }\end{array}$ & $\begin{array}{c}23 \\
(\mathrm{NR})\end{array}$ & $\begin{array}{c}43 \\
(N R)\end{array}$ & 0.002 \\
\hline $\begin{array}{l}\text { Untch et al., } \\
2008 \text { [15] }\end{array}$ & 453 & NA & $\begin{array}{c}\mathrm{EC} \rightarrow \mathrm{D} \text { or } \mathrm{EC} \rightarrow \\
\mathrm{DX} \text { or } \mathrm{EC} \rightarrow \mathrm{D} \rightarrow \\
\quad \mathrm{X} \text { vs. } \\
\mathrm{EC} \rightarrow \mathrm{D}+\mathrm{H} \text { or } \mathrm{EC} \\
\rightarrow \mathrm{DX}+\mathrm{H} \text { or } \mathrm{EC} \rightarrow \\
\mathrm{D}+\mathrm{H} \rightarrow \mathrm{X}+\mathrm{H}\end{array}$ & NA & $\begin{array}{c}20 \\
\text { (NR) }\end{array}$ & $\begin{array}{c}41 \\
\text { (NR) }\end{array}$ & $<0.001$ \\
\hline
\end{tabular}

C, cyclophosphamide; Cl, confidence interval; D, docetaxel; E, epirubicin; F, 5-fluoruracil; FISH, fluorescence in situ hybridization; H, trastuzumab; HER2, human epidermal growth factor receptor 2; IHC, immunohistochemistry; M, methotrexate; N, nodal status; NA, not applicable; NR, not reported; NS, not significant; $\mathrm{P}$, paclitaxel; pCR, pathologic complete response; T, tumour size; $\mathrm{X}$, capecitabine.

populations [31]. Adjuvant registration trials require an enormous financial and patient investment to detect small differences in long-term outcome. A well-designed neoadjuvant study can rapidly provide a 'go/no go' decision for an emerging therapy. Invaluable data for the appropriate selection of patients and the evaluation of endpoints for a subsequent adjuvant registration trial can be generated by a well-designed neoadjuvant pilot trial: this concept is currently being developed and explored by the Breast International Group (Brussels, Belgium).

The proliferation marker Ki67 is another marker of interest to be used as a surrogate marker for efficacy, especially with endocrine therapy $[17,32,33]$. Declines in Ki67 after 2 weeks of neoadjuvant treatment showed no difference between tamoxifen and the combination of tamoxifen and anastrozole in the IMPACT (Immediate Preoperative 'Arimidex' [anastrozole], Tamoxifen, or Arimidex Combined with Tamoxifen) trial, while a significantly greater drop was found in the anastrazole-alone arm [33], mirroring the DFS results of the ATAC (Arimidex, Tamoxifen, Alone or in Combination) trial [34]. If these findings had been known before the launch of the ATAC trial, the combination arm likely would have been dropped from the study design from the outset, thereby saving considerable financial and patient resources.

The eligibility criteria for the ongoing neoadjuvant anti-HER2 studies are similar. With the exception of the National Cancer Institute study [35] that includes only patients with hormone receptor-positive $\left(\mathrm{HR}^{+}\right)$and $\mathrm{HER} 2^{+}$breast cancer, all other studies include $\mathrm{HR}^{+}$and $\mathrm{HR}^{-}$disease. Although $\mathrm{HR}^{+}$and $\mathrm{HR}^{-} \mathrm{HER}^{+}{ }^{+}$breast cancer may exhibit different clinical behaviour [36], the joint inclusion of $\mathrm{HER2}^{+}$disease regardless of HR status in the evaluation of novel anti-HER2 therapy is justified, as trastuzumab has been shown to be effective regardless of the expression of hormonal receptors [37].

Perhaps more controversial is the joint inclusion of IBC together with locally advanced disease in the same study, as IBC represents a separate entity with distinct epidemiology, biology, and long-term outcome [38]. Although gene expression profiling (GEP) has identified the same five subtypes of IBC as originally described for noninflammatory breast cancer, differences in several key pathways and proteins do exist [39]. IBC should be evaluated in separate clinical trials or at least stratification should be planned at the time of randomisation.

In contrast to the classical design, in which an experimental therapy is compared with a standard therapy, examples of novel designs are available amongst the ongoing anti-HER2 neoadjuvant studies: the so-called 'biological window' design and 'learn on the way' design. The biological window design exposes the patients to a short period of therapy with the drug of interest alone to allow for the evaluation of biologic endpoints. This design can also provide valuable insight regarding drug pharmacodynamics and early evidence of drug activity and highlight potential mechanisms of resistance. As this phase of design is purely for research purposes and does not offer patients direct therapeutic benefit, there are ethical concerns that must be respected [40]. A short biological window period can be followed by a more classical design comparing standard neoadjuvant therapy with new combinations, including targeted therapy with curative intent, such as in the neoALTTO trial (Figure 2). In the future, these studies may lead to a reduction in overtreatment with chemotherapy, as they may identify patients with excellent response to targeted therapy alone that can be 


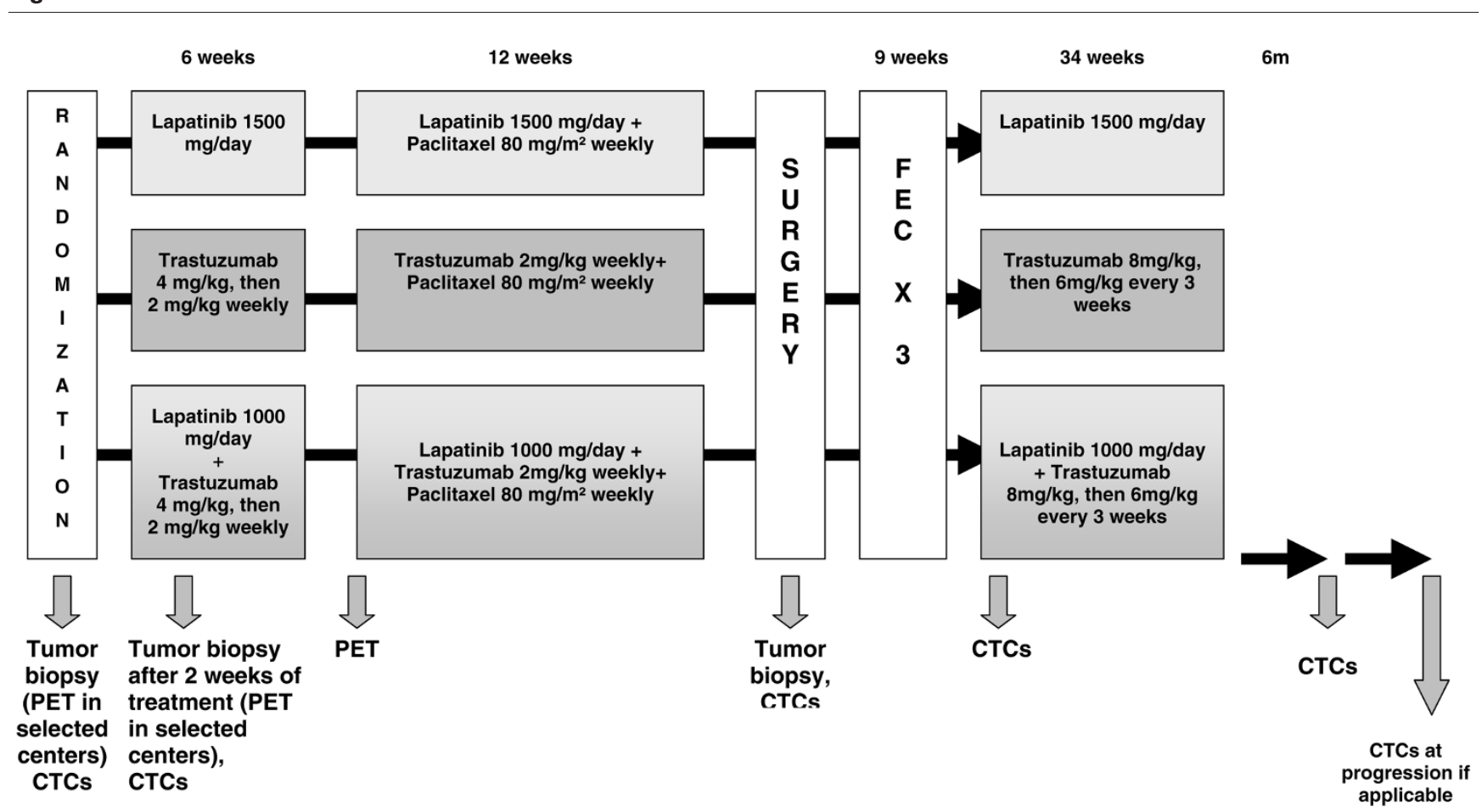

neoALTTO (Neoadjuvant Lapatinib and/or Trastuzumab Treatment Optimisation) study design. CTCs, circulating tumour cells; FEC, 5-fluoruracilepirubicin-cyclophosphamide; PET, positron emission tomography. Note: In the combined Lapatinib + Trastuzumab + Paclitaxel arm, there is a protocol amendment pending approval to reduce the Lapatinib dose to $750 \mathrm{mg} /$ day because of concerns regarding excess diarrhea. Reprinted with permission from GlaxoSmithKline and SOLTI (Spanish Breast Cancer Cooperative Group).

evaluated in a future chemotherapy-sparing study. Though feasible, such neoadjuvant studies require careful planning, enormous logistical support for material collection, and efficient screening systems to identify appropriate patients, all of which significantly increase the complexity and cost of conducting such research.

The 'learn on the way' design uses information gained from an initial treatment period to guide decisions regarding further therapy. A patient who does not demonstrate early clinical response at interim evaluation is unlikely to experience pCR with completion of standard neoadjuvant chemotherapy $[41,42]$. Thus, early-response evaluation can identify a subgroup of patients with poor long-term outcome, providing the opportunity to explore a switch to an alternative therapy to improve the likelihood of pCR. To date, studies evaluating neoadjuvant taxane [41] and capecitabine-vinca alkaloid [42] combinations in nonselected populations have failed to demonstrate a benefit for patients who do not respond to anthracycline-based therapy. The GeparQuinto study described in Figures 3-5 is an example of one such 'learn on the way' approach [7]. The 'learn on the way' design is an excellent opportunity to reduce overtreatment and validate surrogate markers of response. Unfortunately, in the GeparQuinto study, only the nonresponding HER2- ${ }^{-}$cohort will undergo a second randomisation based upon early response, whereas in the HER2 ${ }^{+}$cohort early response is not used to inform further decision-making. In the future, 'learn on the way' designs based upon biomarker endpoints rather than tumour shrinkage may be employed, although there are important challenges regarding the standardisation of cutoff values and interlaboratory reproducibility, along with the need for prompt assessment must be addressed using such a dynamic approach.

\section{Translational research}

The neoadjuvant setting is an ideal platform to evaluate the predictive value of biomarkers using emerging technologies like GEP, proteomics, functional imaging, circulating tumour cells (CTCs), and the role of the host in the response to therapy (pharmacodynamic and pharmacogenetic substudies) (Table 1). Traditionally, translational research in breast cancer has been characterised by efforts to validate single predictive biomarkers using available tumour blocks from completed clinical trials, with largely disappointing results. With new techniques like GEP and biomarker models [43], several putative markers can be linked together to obtain a more powerful prognostic or predictive tool. The biological window design provides an especially valuable opportunity for the rapid evaluation of pharmacodynamic endpoints with biologic therapy. 
Figure 3

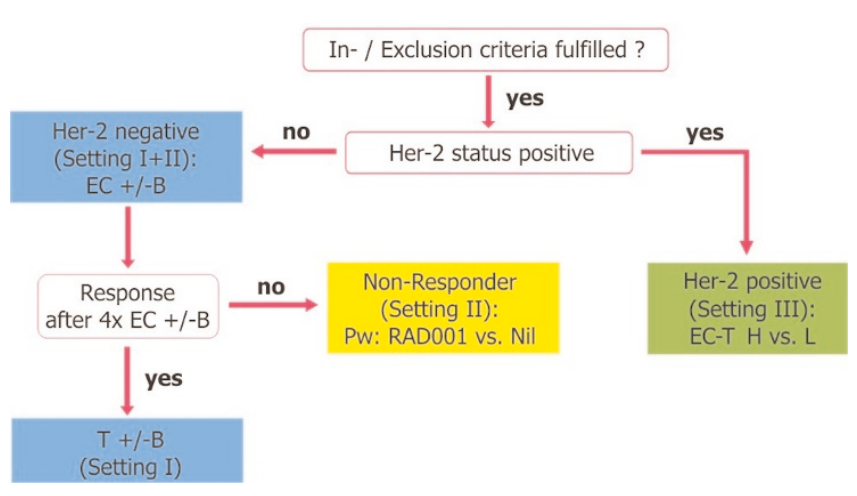

Decision tree from GeparQuinto study. B, bevacizumab; EC, epirubicincyclophosphamide; $\mathrm{H}$, trastuzumab; Her-2, human epidermal growth factor receptor 2; L, lapatinib; Pw, paclitaxel weekly; T, docetaxel. Reprinted with permission from GBG (German Breast Group).

Imaging modalities have not reliably been shown to predict the response to neoadjuvant therapy. This is, in part, because previous validation studies have been conducted in an incomplete and piecemeal manner. Given the rapidly expanding array of new imaging modalities, well-planned neoadjuvant studies with prospective integration of imaging endpoints are required to define and compare the role of molecular and functional imaging as early-response predictors. In contrast to traditional imaging modalities based upon anatomic evaluation of response, functional modalities such as magnetic resonance imaging [44-47], magnetic resonance spectroscopy [48], positron emission tomography $[49,50]$, single photon emission computed tomography [51], ultrasound with enhancement [52], and optical imaging [53] have all shown the ability to predict early response and warrant
Figure 4

Her-2 negative (Setting I + II)

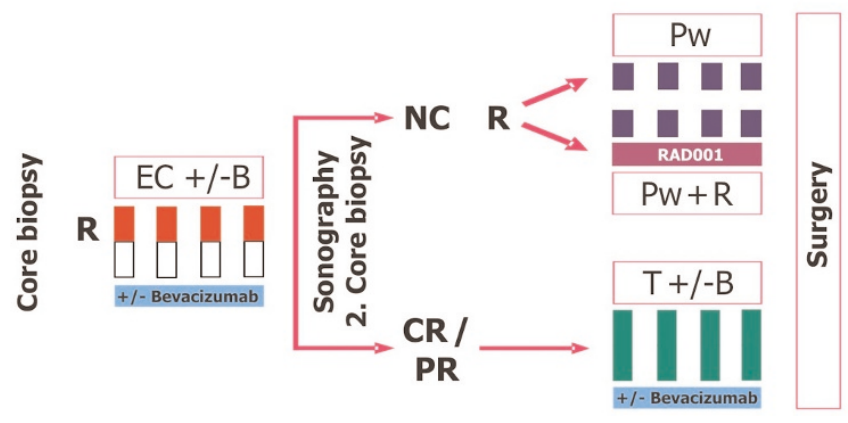

GeparQuinto study design for HER2-negative cohort. B, bevacizumab (15 mg/kg intravenously: day $1 \mathrm{q}$ day 21 for eight cycles); C, cyclophosphamide (600 mg/m²: day 1 q day 21 for four cycles); CR, complete response; $\mathrm{E}$, epirubicin $\left(90 \mathrm{mg} / \mathrm{m}^{2}\right.$ : every 3 weeks for four cycles); Her-2, human epidermal growth factor receptor 2; NC, no change; PR, partial response; Pw, paclitaxel weekly $\left(80 \mathrm{mg} / \mathrm{m}^{2}\right.$ : weekly for 12 weeks total); Pw + R, paclitaxel weekly + RAD001 (5 mg daily); $\mathrm{R}$, randomisation; $\mathrm{T}$, docetaxel $\left(100 \mathrm{mg} / \mathrm{m}^{2}\right.$ : day $1 \mathrm{q}$ day 21 for four cycles). Reprinted with permission from GBG (German Breast Group).

prospective evaluation in phase III clinical trials. In particular, their ability to predict an early response using anti-HER2 therapy still needs to be demonstrated prospectively.

CTCs can be identified in the blood of $10 \%$ to $30 \%$ of patients with early breast cancer and their detection is associated with poor long-term DFS [54-56]. Currently, their prognostic and predictive value is also being investigated in neoadjuvant trials exploring the efficacy of novel anti-HER2 drugs (Table 1). Several methods of CTC detection have been described, although reverse transcription-polymerase

Figure 5

\section{Her-2 positive (Setting III)}

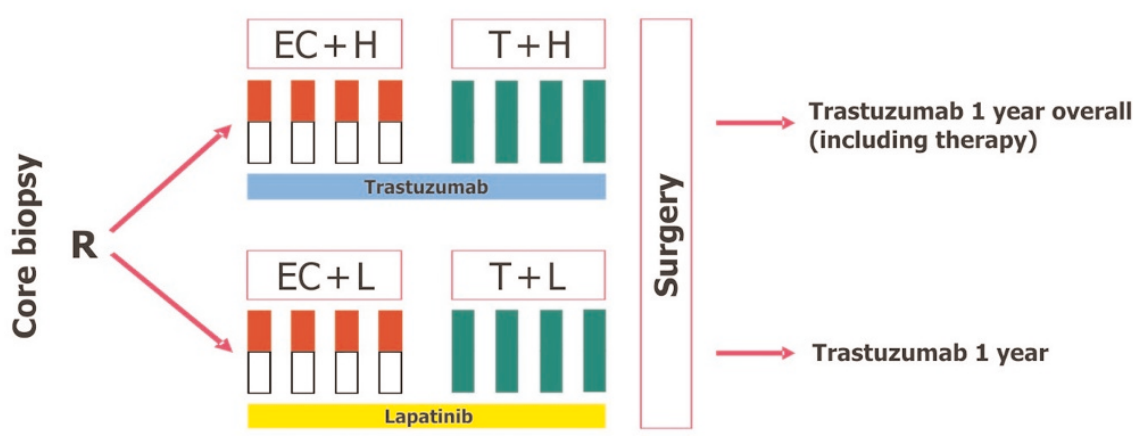

GeparQuinto study design for HER2-positive cohort. C, cyclophosphamide (600 mg/m²: day 1 q day 21 for four cycles); E, epirubicin (90 mg/m²: every 3 weeks for four cycles); $\mathrm{H}$, trastuzumab ( $8 \mathrm{mg} / \mathrm{kg}$ : loading dose, $6 \mathrm{mg} / \mathrm{kg}$ : every 3 weeks); Her-2, human epidermal growth factor receptor 2 ; $\mathrm{L}$, lapatinib (1,250 mg daily for 24 weeks: run-in phase cycles 1 and 5: 1,000 mg daily); R, randomisation; T, docetaxel $\left(100 \mathrm{mg} / \mathrm{m}^{2}\right.$ : every 3 weeks for four cycles). Reprinted with permission from GBG (German Breast Group). 
chain reaction and immunomagnetic/fluorescent approaches are the most advanced $[57,58]$.

Studies exploring the efficacy of novel anti-HER2 drugs not only are tumour-orientated but also will evaluate the role of the host with prospective pharmacogenetic and pharmacodynamic translational research studies. These studies will provide us with valuable knowledge regarding interindividual differences in drug metabolism and the efficacy of novel agents $[59,60]$.

Translational research rarely leads directly to the registration of novel therapies, making it difficult to justify the high costs of adequately powered translational research to industrial trial sponsors [61]. However, innovative neoadjuvant translational research may identify patients likely to benefit from novel therapies that may ultimately reduce the number of participants needed for a subsequent registration study in the adjuvant setting as well as increase the probability of detecting a beneficial effect due to more accurate patient selection. As the examples of trastuzumab for breast cancer and gefitinib for lung cancer treatment illustrate, knowledge of the appropriate patient population for a novel targeted therapy can make the difference between a blockbuster drug and a drug that never makes it to market [62-66].

\section{Conclusions}

Ongoing neoadjuvant studies exploring the efficacy of novel anti-HER2 agents with innovative designs, like the "biological window' and 'learn on the way', promise to deliver new knowledge of breast cancer biology and treatment. In the future, a greater collaborative effort between research groups is required to translate the new insights regarding the molecular heterogeneity of breast cancer into individualised therapies. Past failures have been marred by duplicative trial designs, poorly planned translational research, and overestimation of the benefit of experimental therapy in unselected populations. A new partnership between academic investigators, industry, patients, and policy-makers is needed, with a common understanding that properly conducted innovative neoadjuvant research can transform the dream of tailored therapy for breast cancer into reality.

\section{Competing interests}

FC has received unrestricted research grants from HoffmannLa Roche (Grenzach-Wyhlen, Germany) and GlaxoSmithKline (Uxbridge, Middlesex, UK) and has participated in advisory boards for GlaxoSmithKline. MP has received honoraria from Hoffmann-La Roche, GlaxoSmithKline, AstraZeneca (London, UK), and Novartis (Basel, Switzerland). The other authors declare that they have no competing interests.

\section{References}

1. Chia S, Swain SM, Byrd DR, Mankoff DA: Locally advanced and inflammatory breast cancer. J Clin Oncol 2008, 26:786-790.

2. Bonadonna G, Valagussa P, Brambilla C, Ferrari L, Moliterni A, Terenziani M, Zambetti M: Primary chemotherapy in operable breast cancer: eight-year experience at the Milan Cancer Institute. J Clin Oncol 1998, 16:93-100.

3. Mauri D, Pavlidis N, loannidis JP: Neoadjuvant versus adjuvant systemic treatment in breast cancer: a meta-analysis. J Natl Cancer Inst 2005, 97:188-194.

4. Buchholz TA, Lehman CD, Harris JR, Pockaj BA, Khouri N, Hylton NF, Miller MJ, Whelan T, Pierce LJ, Esserman LJ, Newman LA, Smith BL, Bear HD, Mamounas EP: Statement of the science concerning locoregional treatments after preoperative chemotherapy for breast cancer: a National Cancer Institute conference. J Clin Oncol 2008, 26:791-797.

5. Gralow JR, Burstein HJ, Wood W, Hortobagyi GN, Gianni L, von Minckwitz G, Buzdar AU, Smith IE, Symmans WF, Singh B, Winer EP: Preoperative therapy in invasive breast cancer: pathologic assessment and systemic therapy issues in operable disease. $J$ Clin Oncol 2008, 26:814-819.

6. Rastogi P, Anderson SJ, Bear HD, Geyer CE, Kahlenberg MS, Robidoux A, Margolese RG, Hoehn JL, Vogel VG, Dakhil SR, Tamkus D, King KM, Pajon ER, Wright MJ, Robert J, Paik S, Mamounas EP, Wolmark N: Preoperative chemotherapy: updates of National Surgical Adjuvant Breast and Bowel Project Protocols B-18 and B-27. J Clin Oncol 2008, 26:778785.

7. von Minckwitz G, Blohmer JU, Raab G, Löhr A, Gerber B, Heinrich G, Eidtmann H, Kaufmann M, Hilfrich J, Jackisch C, Zuna I, Costa SD; German Breast Group: In vivo chemosensitivity-adapted preoperative chemotherapy in patients with early-stage breast cancer: the GEPARTRIO pilot study. Ann Oncol 2005, 16:56-63.

8. ClinicalTrials.gov homepage [http://clinicaltrials.gov].

9. Rouzier R, Perou CM, Symmans WF, Ibrahim N, Cristofanilli M, Anderson K, Hess KR, Stec J, Ayers M, Wagner P, Morandi P, Fan C, Rabiul I, Ross JS, Hortobagyi GN, Pusztai L: Breast cancer molecular subtypes respond differently to preoperative chemotherapy. Clin Cancer Res 2005, 11:5678-5685.

10. Penault-Llorca F, Abrial C, Mouret-Reynier M-A, Raoelfils I, Durando X, Leheurteur M, Gimbergues P, Tortochaux J, Cure H, Chollet P: Achieving higher pathological complete response rates in HER-2-positive patients with induction chemotherapy without trastuzumab in operable breast cancer. Oncologist 2007, 12:390-396.

11. Buzdar AU, Ibrahim NK, Francis D, Booser DJ, Thomas ES, Theriault RL, Pusztai L, Green MC, Arun BK, Giordano SH, Cristofanilli $M$, Frye DK, Smith TL, Hunt KK, Singletary SE, Sahin AA, Ewer MS, Buchholz TA, Berry D, Hortobagyi GN: Significantly higher pathologic complete remission rate after neoadjuvant therapy with trastuzumab, paclitaxel, and epirubicin chemotherapy: results of a randomized trial in human epidermal growth factor receptor 2-positive operable breast cancer. J Clin Oncol 2005, 23:3676-3685.

12. Buzdar AU, Valero V, Ibrahim NK, Francis D, Broglio KR, Theriault RL, Pusztai L, Green MC, Singletary SE, Hunt KK, Sahin AA, Esteva F, Symmans WF, Ewer MS, Buchholz TA, Hortobagyi GN: Neoadjuvant therapy with paclitaxel followed by 5 -fluorouracil, epirubicin, and cyclophosphamide chemotherapy and concurrent trastuzumab in human epidermal growth factor receptor 2-positive operable breast cancer: an update of the initial randomized study population and data of additional patients treated with the same regimen. Clin Cancer Res 2007, 13:228-233.

13. Gianni L, Semiglazov V, Manikhas GM, Eiermann W, Lluch A, Tjulandin S, Feyereislova A, Vanhauwere B, Valagussa P, Baselga J: Neoadjuvant trastuzumab in locally advanced breast cancer (NOAH): antitumour and safety analysis. In 2007 ASCO Annual Meeting Proceedings. 43rd American Society of Clinical Oncology Annual Meeting; 1-5 June 2007; Chicago, IL. Abstract 532.

14. Slamon DJ, Leyland-Jones B, Shak S, Fuchs $H$, Paton V, Bajamonde A, Fleming T, Eiermann W, Wolter J, Pegram M, Baselga J, Norton L: Use of chemotherapy plus a monoclonal antibody against HER2 for metastatic breast cancer that overexpresses HER2. N Engl J Med 2001, 344:783-792.

15. Untch M, Rezai M, Loibl S, Fasching PA, Huober J, Tesch $\mathrm{H}$, Bauerfeind I, Hilfrich J, Mehta K, von Minckwitz G: Neoadjuvant treatment of HER2 overexpressing primary breast cancer with trastuzumab given concomitantly to epirubicin/cyclophosphamide followed by docetaxel \pm capecitabine. First analysis 
of efficacy and safety of the GBG/AGO multicenter intergroup-study 'GeparQuattro'. Presented at: 6th European Breast Cancer Conference; 15-19 April 2008; Berlin, Germany. Abstract $1 \mathrm{LB}$

16. Schmid P, Untch M, Kossé V, Bondar G, Vassiljev L, Tarutinov V, Lehmann U, Maubach L, Meurer J, Wallwiener D, Possinger K: Leuprorelin acetate every-3-months depot versus cyclophosphamide, methotrexate, and fluorouracil as adjuvant treatment in premenopausal patients with node-positive breast cancer: the TABLE study. J Clin Oncol 2007, 25:2509-2515.

17. Paik S, Tang G, Shak S, Kim C, Baker J, Kim W, Cronin M, Baehner FL, Watson D, Bryant J, Costantino JP, Geyer CE Jr, Wickerham DL, Wolmark N: Gene expression and benefit of chemotherapy in women with node-negative, estrogen receptor-positive breast cancer. J Clin Oncol 2006, 24:3726-3734.

18. Hudis C, Modi S: Preoperative chemotherapy for breast cancer: miracle or mirage? JAMA 2007, 298:2665-2667.

19. Harris L, Fritsche H, Mennel R, Norton L, Ravdin P, Taube S, Somerfield MR, Hayes DF, Bast RC Jr.: American Society of Clinical Oncology 2007 update of recommendations for the use of tumor markers in breast cancer. $J$ Clin Oncol 2007, 25: $5287-5312$

20. Trastuzumab with or without everolimus in treating women with breast cancer that can be removed by surgery [http://www.clinicaltrials.gov/ct2/show/NCT00674414?term=nct 00674414\&rank=1].

21. Minna JD, Girard L, Xie Y: Tumor mRNA expression profiles predict responses to chemotherapy. J Clin Oncol 2007, 25: 4329-4336.

22. Roché H, Fumoleau $P$, Spielmann $M$, Canon JL, Delozier T, Serin $D$, Symann M, Kerbrat $P$, Soulié $P$, Eichler $F$, Viens $P$, Monnier A, Vindevoghel A, Campone M, Goudier MJ, Bonneterre J, Ferrero JM, Martin AL, Genève J, Asselain B: Sequential adjuvant epirubicin-based and docetaxel chemotherapy for node-positive breast cancer patients: the FNCLCC PACS 01 Trial. J Clin Oncol 2006, 24:5664-5671.

23. Goldstein L, O'Neill A, Sparano J, Perez E, Shulman L, Martino S, Davidson N: E2197: Phase III AT (doxorubicin/docetaxel) vs. AC (doxorubicin/cyclophosphamide) in the adjuvant treatment of node positive and high risk node negative breast cancer. In 2005 ASCO Annual Meeting Proceedings. 41st American Society of Clinical Oncology Annual Meeting; 13-17 May 2005; Orlando, FL. Abstract 512.

24. Henderson IC, Berry DA, Demetri GD, Cirrincione CT, Goldstein LJ, Martino S, Ingle JN, Cooper MR, Hayes DF, Tkaczuk KH, Fleming G, Holland JF, Duggan DB, Carpenter JT, Frei E 3rd, Schilsky RL, Wood WC Muss HB, Norton L: Improved outcomes from adding sequential Paclitaxel but not from escalating Doxorubicin dose in an adjuvant chemotherapy regimen for patients with node-positive primary breast cancer. J Clin Oncol 2003, 21:976-983.

25. Bear HD, Anderson S, Smith RE, Geyer CE Jr., Mamounas EP, Fisher B, Brown AM, Robidoux A, Margolese R, Kahlenberg MS, Paik S, Soran A, Wickerham DL, Wolmark N: Sequential preoperative or postoperative docetaxel added to preoperative doxorubicin plus cyclophosphamide for operable breast cancer: National Surgical Adjuvant Breast and Bowel Project Protocol B-27. J Clin Oncol 2006, 24:2019-2027.

26. Fisher B, Bryant J, Wolmark N, Mamounas E, Brown A, Fisher ER, Wickerham DL, Begovic M, DeCillis A, Robidoux A, Margolese RG, Cruz AB Jr., Hoehn JL, Lees AW, Dimitrov NV, Bear HD: Effect of preoperative chemotherapy on the outcome of women with operable breast cancer. J Clin Oncol 1998, 16: 2672-2685

27. Symmans WF, Peintinger $F$, Hatzis $C$, Rajan R, Kuerer H, Valero V, Assad L, Poniecka A, Hennessy B, Green M, Buzdar AU, Singletary SE, Hortobagyi GN, Pusztai L: Measurement of residual breast cancer burden to predict survival after neoadjuvant chemotherapy. J Clin Oncol 2007, 25:4414-4422.

28. Hudis CA, Barlow WE, Costantino JP, Gray RJ, Pritchard KI, Chapman JA, Sparano JA, Hunsberger S, Enos RA, Gelber RD, Zujewski JA: Proposal for standardized definitions for efficacy end points in adjuvant breast cancer trials: the STEEP system. J Clin Oncol 2007, 25:2127-2132.

29. Coudert BP, Largillier $R$, Arnould $L$, Chollet $P$, Campone $M$, Coeffic D, Priou F, Gligorov J, Martin X, Trillet-Lenoir V, Weber B, Bleuse JP, Vasseur B, Serin D, Namer M: Multicenter phase II trial of neoadjuvant therapy with trastuzumab, docetaxel, and carboplatin for human epidermal growth factor receptor-2overexpressing stage II or III breast cancer: results of the GETN(A)-1 trial. J Clin Oncol 2007, 25:2678-2684.

30. Thomas E, Holmes FA, Smith TL, Buzdar AU, Frye DK, Fraschini G, Singletary SE, Theriault RL, McNeese MD, Ames F, Walters R, Hortobagyi GN: The use of alternate, non-cross-resistant adjuvant chemotherapy on the basis of pathologic response to a neoadjuvant doxorubicin-based regimen in women with operable breast cancer: long-term results from a prospective randomized trial. J Clin Oncol 2004, 22:2294-2302.

31. Poole CJ, Hiller L, Howard HC, Dunn JA, Canney P, Wardley AM, Kennedy MJ, Coleman RE, Leonard RC, Earl HM, tAnGo trial collaborators: tAnGo: a randomized phase III trial of gemcitabine (gem) in paclitaxel-containing, epirubicin/cyclophosphamidebased, adjuvant chemotherapy (CT) for women with earlystage breast cancer (EBC). In 2008 ASCO Annual Meeting Proceedings. 44th American Society of Clinical Oncology Annual Meeting; 1-5 June 2008; Chicago, IL. Abstract 532.

32. Dowsett M, Smith IE, Ebbs SR, Dixon JM, Skene A, A'Hern R, Salter J, Detre S, Hills M, Walsh G: Prognostic value of Ki67 expression after short-term presurgical endocrine therapy for primary breast cancer. J Natl Cancer Inst 2007, 99:167-170.

33. Dowsett M, Smith IE, Ebbs SR, Dixon JM, Skene A, Griffith C Boeddinghaus I, Salter J, Detre S, Hills M, Ashley S, Francis S, Walsh G; IMPACT Trialists: Short-term changes in Ki-67 during neoadjuvant treatment of primary breast cancer with anastrozole or tamoxifen alone or combined correlate with recurrence-free survival. Clin Cancer Res 2005, 11(2 Pt 2): 951s-958s.

34. Baum M, Buzdar A, Cuzick J, Forbes J, Houghton J, Howell A Sahmoud T: Anastrozole alone or in combination with tamoxifen versus tamoxifen alone for adjuvant treatment of postmenopausal women with early-stage breast cancer: results of the ATAC (Arimidex, Tamoxifen Alone or in Combination) trial efficacy and safety update analyses. Cancer 2003, 98:18021810.

35. Letrozole and lapatinib in treating postmenopausal women with stage I, stage II, or stage III breast cancer that can be removed by surgery [http://clinicaltrials.gov/ct2/show/NCT00499681].

36. Nguyen PL, Taghian AG, Katz MS, Niemierko A, Abi Raad RF, Boon WL, Bellon JR, Wong JS, Smith BL, Harris JR: Breast cancer subtype approximated by estrogen receptor, progesterone receptor, and HER-2 is associated with local and distant recurrence after breast-conserving therapy. J Clin Oncol 2008, 26:2373-2378.

37. Untch M, Gelber RD, Jackisch C, Procter M, Baselga J, Bell R, Cameron D, Bari M, Smith I, Leyland-Jones B, de Azambuja E, Wermuth P, Khasanov R, Feng-Yi F, Constantin C, Mayordomo Jl, $\mathrm{Su} \mathrm{CH}, \mathrm{Yu}$ SY, Lluch A, Senkus-Konefka $\mathrm{E}$, Price $\mathrm{C}$, Haslbauer $\mathrm{F}$ Suarez Sahui T, Srimuninnimit V, Colleoni M, Coates AS, PiccartGebhart MJ, Goldhirsch A; HERA Study Team: Estimating the magnitude of trastuzumab effects within patient subgroups in the HERA trial. Ann Oncol 2008, 19:1090-1096.

38. Anderson WF, Chu KC, Chang S: Inflammatory breast carcinoma and noninflammatory locally advanced breast carcinoma: distinct clinicopathologic entities? J Clin Oncol 2003, 21:2254-2259.

39. Bertucci F, Finetti P, Rougemont J, Charafe-Jauffret E, Cervera N Tarpin C, Nguyen C, Xerri L, Houlgatte R, Jacquemier J, Viens P, Birnbaum D: Gene expression profiling identifies molecular subtypes of inflammatory breast cancer. Cancer Res 2005, 65: 2170-2178.

40. Agulnik M, Oza AM, Pond GR, Siu LL: Impact and perceptions of mandatory tumor biopsies for correlative studies in clinical trials of novel anticancer agents. J Clin Oncol 2006, 24:4801 4807.

41. Evans TR, Yellowlees A, Foster E, Earl H, Cameron DA, Hutcheon AW, Coleman RE, Perren T, Gallagher CJ, Quigley M, Crown J, Jones AL, Highley M, Leonard RC, Mansi JL: Phase III randomized trial of doxorubicin and docetaxel versus doxorubicin and cyclophosphamide as primary medical therapy in women with breast cancer: an anglo-celtic cooperative oncology group study. J Clin Oncol 2005, 23:2988-2995.

42. von Minckwitz $G$, Kümmel $S$, Vogel $P$, Hanusch $C$, Eidtmann $H$ Hilfrich J, Gerber B, Huober J, Costa SD, Jackisch C, Loibl S, Mehta K, Kaufmann M; German Breast Group: Neoadjuvant 
vinorelbine-capecitabine versus docetaxel-doxorubicincyclophosphamide in early nonresponsive breast cancer: phase III randomized GeparTrio trial. J Natl Cancer Inst 2008, 100:542-551.

43. Ellis MJC: Neoadjuvant therapy for breast cancer. In ASCO Educational Book, Spring 2008. Alexandria, VA: American Society of Clinical Oncology; 2008:55-57.

44. Chen JH, Feig B, Agrawal G, Yu H, Carpenter PM, Mehta RS, Nalcioglu O, Su MY: MRI evaluation of pathologically complete response and residual tumors in breast cancer after neoadjuvant chemotherapy. Cancer 2008, 112:17-26.

45. Esserman L, Kaplan E, Partridge S, Tripathy D, Rugo H, Park J, Hwang S, Kuerer H, Sudilovsky D, Lu Y, Hylton N: MRI phenotype is associated with response to doxorubicin and cyclophosphamide neoadjuvant chemotherapy in stage III breast cancer. Ann Surg Oncol 2001, 8:549-559.

46. Padhani AR, Hayes C, Assersohn L, Powles T, Makris A, Suckling J, Leach MO, Husband JE: Prediction of clinicopathologic response of breast cancer to primary chemotherapy at contrast-enhanced MR imaging: initial clinical results. Radiology 2006, 239:361-374.

47. Partridge SC, Gibbs JE, Lu Y, Esserman LJ, Tripathy D, Wolverton DS, Rugo HS, Hwang ES, Ewing CA, Hylton NM: MRI measurements of breast tumor volume predict response to neoadjuvant chemotherapy and recurrence-free survival. AJR Am J Roentgenol 2005, 184:1774-1781.

48. Meisamy S, Bolan PJ, Baker EH, Bliss RL, Gulbahce E, Everson LI, Nelson MT, Emory TH, Tuttle TM, Yee D, Garwood M: Neoadjuvant chemotherapy of locally advanced breast cancer: predicting response with in vivo (1)H MR spectroscopy-a pilot study at 4 T. Radiology 2004, 233:424-431.

49. Schelling M, Avril N, Nährig J, Kuhn W, Römer W, Sattler D, Werner M, Dose J, Jänicke F, Graeff H, Schwaiger M: Positron emission tomography using [(18)F]Fluorodeoxyglucose for monitoring primary chemotherapy in breast cancer. $J$ Clin Oncol 2000, 18:1689-1695.

50. Smith IC, Welch AE, Hutcheon AW, Miller ID, Payne S, Chilcott F, Waikar S, Whitaker T, Ah-See AK, Eremin O, Heys SD, Gilbert FJ, Sharp PF: Positron emission tomography using [(18)F]-fluorodeoxy-D-glucose to predict the pathologic response of breast cancer to primary chemotherapy. J Clin Oncol 2000, 18:1676-1688.

51. Dunnwald LK, Gralow JR, Ellis GK, Livingston RB, Linden HM, Lawton TJ, Barlow WE, Schubert EK, Mankoff DA: Residual tumor uptake of [99mTc]-sestamibi after neoadjuvant chemotherapy for locally advanced breast carcinoma predicts survival. Cancer 2005, 103:680-688.

52. Bloch SH, Dayton PA, Ferrara KW: Targeted imaging using ultrasound contrast agents. Progess and opportunities for clinical and research applications. IEEE Eng Med Biol Mag 2004, 23:18-29.

53. Tromberg BJ, Cerussi A, Shah N, Compton M, Durkin A, Hsiang $D$, Butler J, Mehta R: Imaging in breast cancer: diffuse optics in breast cancer: detecting tumors in pre-menopausal women and monitoring neoadjuvant chemotherapy. Breast Cancer Res 2005, 7:279-285

54. Stathopoulos EN, Sanidas E, Kafousi M, Mavroudis D, Askoxylakis J, Bozionelou V, Perraki M, Tsiftsis D, Georgoulias V: Detection of CK-19 mRNA-positive cells in the peripheral blood of breast cancer patients with histologically and immunohistochemically negative axillary lymph nodes. Ann Oncol 2005, 16:240246.

55. Xenidis N, Perraki M, Kafousi M, Apostolaki S, Bolonaki I, Stathopoulou A, Kalbakis K, Androulakis N, Kouroussis C, Pallis T, Christophylakis C, Argyraki K, Lianidou ES, Stathopoulos S, Georgoulias V, Mavroudis D: Predictive and prognostic value of peripheral blood cytokeratin-19 mRNA-positive cells detected by real-time polymerase chain reaction in node-negative breast cancer patients. J Clin Oncol 2006, 24:3756-3762.

56. Stathopoulou A, Ntoulia M, Perraki M, Apostolaki S, Mavroudis D, Malamos N, Georgoulias V, Lianidou ES: A highly specific realtime RT-PCR method for the quantitative determination of CK19 mRNA positive cells in peripheral blood of patients with operable breast cancer. Intl J Cancer 2006, 119:1654-1659.

57. Ghossein RA, Carusone L, Bhattacharya S: Review: polymerase chain reaction detection of micrometastases and circulating tumor cells: application to melanoma, prostate, and thyroid carcinomas. Diagn Mol Pathol 1999, 8:165-175.

58. Allard WJ, Matera J, Miller MC, Repollet M, Connelly MC, Rao C, Tibbe AG, Uhr JW, Terstappen LW: Tumor cells circulate in the peripheral blood of all major carcinomas but not in healthy subjects or patients with nonmalignant diseases. Clin Cancer Res 2004, 10:6897-6904.

59. Goetz MP, Rae JM, Suman VJ, Safgren SL, Ames MM, Visscher DW, Reynolds C, Couch FJ, Lingle WL, Flockhart DA, Desta Z, Perez EA, Ingle JN: Pharmacogenetics of tamoxifen biotransformation is associated with clinical outcomes of efficacy and hot flashes. J Clin Oncol 2005, 23:9312-9318.

60. Punglia RS, Burstein HJ, Winer EP, Weeks JC: Pharmacogenomic variation of CYP2D6 and the choice of optimal adjuvant endocrine therapy for postmenopausal breast cancer: a modeling analysis. J Nat/ Cancer Inst 2008, 100:642-648.

61. Piccart M, Goldhirsch A, Wood W, Pritchard K, Baselga J, Reaby L, Kossler I, Kyriakides S, Norton L, Coates A: Keeping faith with trial volunteers. Nature 2007, 446:137-138.

62. Giaccone G, Herbst RS, Manegold C, Scagliotti G, Rosell R, Miller V, Natale RB, Schiller JH, Von Pawel J, Pluzanska A, Gatzemeier U, Grous J, Ochs JS, Averbuch SD, Wolf MK, Rennie P, Fandi A, Johnson DH: Gefitinib in combination with gemcitabine and cisplatin in advanced non-small-cell lung cancer: a phase III trial-INTACT 1. J Clin Oncol 2004, 22:777-784.

63. Herbst RS, Giaccone G, Schiller JH, Natale RB, Miller V, Manegold C, Scagliotti G, Rosell R, Oliff I, Reeves JA, Wolf MK, Krebs AD, Averbuch SD, Ochs JS, Grous J, Fandi A, Johnson DH: Gefitinib in combination with paclitaxel and carboplatin in advanced non-small-cell lung cancer: a phase III trial-INTACT 2. J Clin Oncol 2004, 22:785-794.

64. Cufer T, Vrdoljak E, Gaafar R, Erensoy I, Pemberton K: Phase II, open-label, randomized study (SIGN) of single-agent gefitinib (IRESSA) or docetaxel as second-line therapy in patients with advanced (stage IIIb or IV) non-small-cell lung cancer. Anticancer Drugs 2006, 17:401-409.

65. Fukuoka M, Yano S, Giaccone G, Tamura T, Nakagawa K, Douillard JY, Nishiwaki Y, Vansteenkiste J, Kudoh S, Rischin D, Eek R, Horai T, Noda K, Takata I, Smit E, Averbuch S, Macleod A, Feyereislova A, Dong RP, Baselga J: Multi-institutional randomized phase II trial of gefitinib for previously treated patients with advanced non-small-cell lung cancer (The IDEAL 1 Trial) [corrected]. J Clin Oncol 2003, 21:2237-2246.

66. Cohen MH, Williams GA, Sridhara R, Chen G, Pazdur R: FDA drug approval summary: gefitinib (ZD1839) (Iressa) tablets. Oncologist 2003, 8:303-306. 